\title{
ANALISIS BIAYA DAN PENDAPATAN USAHATANI JAGUNG HIBRIDA DI DESA CIHAUR KECAMATAN MAJA KABUPATEN MAJALENGKA
}

\author{
COST AND INCOME ANALYSIS OF HYBRID CORN FARMING \\ IN CIHAUR VILLAGE MAJA DISTRICT MAJALENGKA REGENCY
}

\author{
Vina Rachmadina*, Zumi Saidah, Lucyana Trimo, Eliana Wulandari \\ Universitas Padjadjaran, Jl. Raya Sumedang-Bandung, Jawa Barat 45363 \\ *Email: vrachmadina@gmail.com \\ (Diterima 28-12-2020; Disetujui 14-1-2021)
}

\begin{abstract}
ABSTRAK
Jagung merupakan salah satu tanaman pangan dengan nilai ekonomis yang tinggi mengingat kedudukannya sebagai sumber utama karbohidrat dan protein pengganti beras juga dapat digunakan sebagai bahan baku pakan ternak yang memiliki komposisi cukup dominan. Kabupaten Majalengka merupakan salah satu kabupaten di Provinsi Jawa Barat yang memiliki kedudukan sebagai daerah penghasil jagung dengan jumlah produksi 151.646 ton pada tahun 2017. Tujuan dari penelitian ini adalah untuk mengetahui: (1) Besarnya biaya produksi pada usahatani jagung hibrida per satu kali musim tanam, (2) Besarnya pendapatan dan penerimaan usahatani jagung hibrida per satu kali musim tanam. Penelitian ini adalah penelitian kuantitatif dengan analisis deskriptif yang dilakukan di Desa Cihaur, Kecamatan Maja, Kabupaten Majalengka. Teknik pengambilan sampel yang digunakan adalah simple random sampling dari anggota populasi yang berjumlah 180 orang, dan diambil responden sebanyak 64 orang. Hasil penelitian menunjukkan bahwa: 1) Besarnya biaya produksi pada usahatani jagung hibrida sebesar Rp3.686.567,97 per 0,77 ha per satu kali musim tanam, 2) Besarnya pendapatan pada usahatani jagung hibrida sebesar Rp6.070.791,41 per 0,77 ha per satu kali musim tanam dan penerimaan sebesar Rp9.757.359,38 per 0,77 ha per satu kali musim tanam. Berdasarkan analisis $\mathrm{R} / \mathrm{C}$ dan $\mathrm{B} / \mathrm{C}$ Ratio, usahatani jagung hibrida di Desa Cihaur Kecamatan Maja Kabupaten Majalengka layak dan menguntungkan untuk diusahakan.
\end{abstract}

Kata kunci: Biaya produksi, Pendapatan, Usahatani, Jagung Hibrida

\begin{abstract}
Corn is a food crop with high economic value considering its position as the main source of carbohydrates and protein substitute rice also be used as raw material for animal feed which has a fairly dominant composition. Majalengka Regency is one of the districts in West Java Province which has a position as a corn producing area with a total production of 151,646 tons in 2017. The purpose of this study is to determine: (1) The amount of production costs in hybrid corn farming per one planting season, (2) The amount of hybrid corn farming income and revenue per one planting season. This research is a quantitative research with descriptive analysis which conducted in Cihaur Village, Maja District, Majalengka Regency. The sampling technique used was simple random sampling of 180 population members and 64 respondents were taken. The results showed that: 1) The amount of production costs in hybrid corn farming is Rp3.686.567,97 per 0,77 ha per one planting season, 2) The amount of income in hybrid corn farming is Rp6.070.791,41 per 0,77 ha per one planting season and revenue in corn farming is Rp9.757.359,38 per 0,77 ha per one planting season. Based on $R / C$ and $B / C$ Ratio analysis, hybrid corn farming in Cihaur Village Maja District Majalengka Regency is feasible and profitable to cultivate.
\end{abstract}

Keywords: Production cost, Income, Farming, Hybrid Corn 


\section{PENDAHULUAN}

Indonesia termasuk dalam sepuluh negara dengan ketersediaan jagung untuk konsumsi terbesar di dunia pada tahun 2013-2018 yaitu dengan rata-rata persediaan jagung sebanyak 12.200 ton (Pusdatin, 2018). Menurut BPS (2019), pada tahun 2018 Provinsi Jawa Barat merupakan provinsi yang memiliki total produksi jagung yang cukup besar dibandingkan dengan provinsi lain, yaitu mencapai sekitar 1,5 juta ton. Produksi dan luas panen jagung di Provinsi Jawa Barat mengalami peningkatan pada tahun 2018 dapat dilihat pada Tabel 1.

Tabel 1. Produksi, Produktivitas, dan Luas Panen Jagung di Provinsi Jawa Barat, Tahun 2014-2018

\begin{tabular}{cccc}
\hline Tahun & $\begin{array}{c}\text { Produksi } \\
\text { (Ton) }\end{array}$ & $\begin{array}{c}\text { Produkti- } \\
\text { vitas } \\
\text { (Ton/Ha) }\end{array}$ & $\begin{array}{c}\text { Luas } \\
\text { Panen } \\
\text { (Ha) }\end{array}$ \\
\hline 2014 & 1.047 .077 & 7,32 & 142.964 \\
2015 & 959.933 & 7,57 & 126.828 \\
2016 & 1.630 .238 & 8,17 & 199.587 \\
2017 & 1.424 .928 & 8,04 & 177.296 \\
$\mathbf{2 0 1 8}$ & $\mathbf{1 . 5 5 0 . 9 6 6}$ & $\mathbf{7 , 6 3}$ & $\mathbf{2 0 3 . 2 6 8}$ \\
\hline \multicolumn{4}{l}{ Sumber: Badan Pusat Statistik (2019) }
\end{tabular}

Tabel 1 menunjukkan bahwa terjadi peningkatan produksi yang semula sebesar 1.424.928 ton menjadi 1.550.966 ton dengan peningkatan sebanyak 126.038 ton. Menurut BPS (2018), Kabupaten Majalengka merupakan salah satu Kabupaten di Provinsi Jawa Barat yang memiliki kedudukan sebagai daerah penghasil jagung diikuti beberapa daerah lainnya seperti Tasikmalaya, Sumedang, dan Sukabumi. Luas Panen, Produksi, dan Produktivitas jagung di Kabupaten Majalengka dapat dilihat pada Tabel 2.

Tabel 2. Luas Panen, Produksi dan Produktivitas Jagung hibrida di Kabupaten Majalengka, Tahun 2014-2017

\begin{tabular}{cccc}
\hline $\begin{array}{c}\text { Kabupaten } \\
\text { Majalengka }\end{array}$ & $\begin{array}{c}\text { Luas } \\
\text { Panen } \\
\text { (Ha) }\end{array}$ & $\begin{array}{c}\text { Produksi } \\
\text { (Ton) }\end{array}$ & $\begin{array}{c}\text { Produkti- } \\
\text { vitas } \\
\text { (Ton/Ha) }\end{array}$ \\
\hline 2014 & 15.911 & 119.335 & 7,50 \\
2015 & 15.587 & 116.852 & 7,50 \\
2016 & 17.877 & 141.559 & 7,92 \\
2017 & 19.075 & 151.646 & 7,95 \\
\hline
\end{tabular}

Sumber: BPS Kabupaten Majalengka (20162019)

Pada Tabel 2 didapatkan bahwa pada tahun 2017 jumlah produksi jagung di Kabupaten Majalengka mengalami peningkatan sebesar 10.087 ton. Peningkatan jumlah produksi pada sektor pangan, diharapkan mampu meningkatkan harga jual petani sehingga penerimaan yang didapatkan oleh petani semakin banyak dan akan berdampak terhadap pendapatan usahatani tersebut. Saat ini, masih adanya petani yang tidak dapat menikmati keuntungan akibat dari tingginya biaya yang dikeluarkan dalam memproduksi komoditas mereka. Upaya peningkatan ketersediaan pangan mengharuskan petani untuk memproduksi dalam jumlah banyak sehingga kebutuhan terhadap barang pokok akan terus terpenuhi. Usaha petani dalam meningkatkan jumlah produksi 
mengakibatkan terjadinya pengeluaran biaya yang lebih besar yang akan berdampak kepada harga jual petani tersebut.

Biaya tersebut diantaranya adalah biaya produksi dan biaya usahatani. Menurut Mubyarto (1989), biaya produksi merupakan keseluruhan pengeluaran yang diperlukan untuk menghasilkan suatu produk tertentu dalam satu kali proses produksi. Biaya produksi terbagi menjadi dua yaitu biaya tetap dan biaya variabel. Menurut BPS (2019), biaya produksi yang terdapat pada komoditas jagung menurut produksi dan ongkos produksinya di Indonesia adalah Rp24.583.000 per musim tanam per hektar.

Menurut Siregar (2011), biaya usahatani merupakan biaya yang terdiri dari biaya yang dibayarkan dan biaya yang diperhitungkan. Biaya yang dibayarkan adalah biaya yang dikeluarkan dengan uang, seperti biaya pembelian sarana input produksi (bibit, pupuk dan obat-obatan) serta biaya upah tenaga kerja. Biaya yang diperhitungkan adalah biaya yang hanya dihitung seperti besarnya pendapatan petani, modal, dan nilai kerja keluarga.

Berdasarkan latar belakang tersebut, maka penelitian ini bertujuan untuk mengetahui: (1) Besarnya biaya produksi pada usahatani jagung hibrida per satu kali musim tanam, (2) Besarnya pendapatan dan penerimaan usahatani jagung hibrida per satu kali musim tanam,

\section{METODE PENELITIAN}

Objek dalam penelitian ini adalah struktur biaya produksi dan pendapatan yang terdapat pada usahatani jagung hibrida. Tempat penelitian dilaksanakan pada usahatani jagung hibrida tepatnya di Desa Cihaur, Kecamatan Maja, Kabupaten Majalengka, Provinsi Jawa Barat. Pemilihan lokasi tersebut untuk menjadi tempat penelitian karena Kabupaten Majalengka merupakan salah satu sentra produksi terbesar untuk komoditas jagung di Provinsi Jawa Barat (BPS, 2018).

Jenis data yang digunakan adalah data cross section tahun 2020. Penelitian ini menggunakan teknik probability sampling dengan metode simple random sampling dalam menentukan responden. Dengan menggunakan rumus slovin didapatkan sejumlah 64 responden petani jagung hibrida di Desa Cihaur, Kecamatan Maja, Kabupaten Majalengka. 
Analisis yang digunakan untuk menjawab tujuan dalam penelitian ini antara lain:

\section{1) Analisis Biaya}

Perhitungan total biaya diperoleh dari jumlah biaya tetap (Fixed Cost) dan biaya variabel (Variable Cost) dengan rumus sebagai berikut:

$$
T C=F C+V C
$$

Keterangan:

$\mathrm{TC}=$ Biaya Total $(\mathrm{Rp} / \mathrm{Musim}$ Tanam $)$

$\mathrm{FC}=$ Biaya Tetap (Rp/Musim Tanam)

$\mathrm{VC}=$ Biaya Variabel (Rp/Musim Tanam)

\section{2) Analisis Penerimaan}

Penerimaan usahatani merupakan hasil perkalian antara jumlah produksi dengan harga jual dalam usahatani jagung hibrida. Rumus untuk menghitung besarnya penerimaan usahatani adalah sebagai berikut:

$$
T R=Y x P y
$$

Keterangan:

$\mathrm{TR}=$ Penerimaan Usahatani $(\mathrm{Rp} /$ Musim Tanam); $\mathrm{Y}=$ Jumlah Produksi (Kg/Musim Tanam); Py = Harga Jual $(\mathrm{Rp} / \mathrm{Kg})$

\section{3) Analisis Pendapatan}

Pendapatan usahatani merupakan selisih antara penerimaan yang diperoleh dari usahatani jagung hibrida dengan seluruh biaya yang dikeluarkan dalam melakukan usahatani jagung hibrida. Rumus untuk menghitung besarnya pendapatan usahatani adalah sebagai berikut:

$$
P b=T R-T C
$$

Keterangan:

$\mathrm{Pb}=$ Pendapatan Bersih Usahatani (Rp/Musim Tanam); $\mathrm{TR}=$ Penerimaan Usahatani (Rp/Musim Tanam); $\mathrm{TC}=$ Total Biaya (Rp/Musim Tanam)

\section{4) Analisis $R / C$}

$\mathrm{R} / \mathrm{C}$ merupakan perbandingan antara penerimaan dengan total biaya yang dikeluarkan dalam usahatani jagung hibrida yang dihitung dengan menggunakan rumus sebagai berikut:

$$
R / C=T R / T C
$$

Keterangan:

$\mathrm{R} / \mathrm{C}=$ Rasio penerimaan terhadap total biaya; $\mathrm{TR}=$ Penerimaan Usahatani (Rp/Musim Tanam); TC = Total Biaya (Rp/Musim Tanam).

Apabila R/C lebih besar dari 1 (R/C $>1)$ maka usahatani tersebut menguntungkan, sedangkan apabila R/C lebih kecil dari $1 \quad(\mathrm{R} / \mathrm{C}<1)$ maka usahatani tersebut tidak menguntungkan untuk diusahakan (Shinta, 2011).

\section{5) Analisis B/C}

$\mathrm{B} / \mathrm{C}$ merupakan perbandingan antara penerimaan dengan total biaya 
yang dikeluarkan dalam usahatani jagung hibrida yang dihitung dengan menggunakan rumus sebagai berikut:

$$
B / C=P b / V C
$$

Keterangan:

$\mathrm{B} / \mathrm{C}=$ Rasio penerimaan terhadap total biaya; $\mathrm{Pb}=$ Pendapatan Usahatani $(\mathrm{Rp} /$ Musim Tanam); $\mathrm{TC}=$ Total Biaya (Rp/Musim Tanam).

Apabila B/C lebih besar dari $1(\mathrm{~B} / \mathrm{C}$ >1) maka usahatani tersebut memiliki manfaat yang lebih besar dari biaya yang dikeluarkan sehingga layak dan efisien, sedangkan apabila B/C lebih kecil dari 1 $(\mathrm{B} / \mathrm{C}<1)$ maka manfaat yang didapatkan lebih kecil dari biaya yang dikeluarkan sehingga usahatani tersebut tidak layak dan efisien untuk diusahakan (Shinta, 2011).

\section{HASIL DAN PEMBAHASAN}

\section{Analisis Biaya Usahatani Jagung Hibrida}

Berdasarkan penelitian yang dilakukan oleh Purwanto et al (2015), petani berkaitan erat dengan beban biaya yang harus dikeluarkan dan diperhitungkan untuk memenuhi kebutuhan produksi. Biaya tersebut dibagi menjadi dua bagian menurut sifatnya yaitu biaya tetap (fixed cost) dan biaya variabel (variable cost). Rata-rata biaya produksi pada usahatani jagung di Desa Modo Kecamatan Bukal Kabupaten Buol adalah sebesar Rp6.260.881 per ha per satu kali musim tanam. Biaya produksi pada penelitian ini dijelaskan sebagai berikut

a) Biaya Tetap

Biaya tetap merupakan biaya tidak habis terpakai dalam satu kali proses produksi atau dapat digunakan kembali dalam proses produksi yang dikeluarkan oleh petani. Biaya tetap terdiri dari biaya pajak lahan, sewa lahan, dan penyusutan alat. Pada penelitian ini, petani jagung hibrida di Desa Cihaur Kecamatan Maja mengeluarkan rata-rata biaya tetap sebesar Rp1.215.335,94 per satu kali musim tanam.

\section{b) Biaya Variabel}

Biaya variabel merupakan biaya yang dapat mempengaruhi besar kecilnya produksi yang dihasilkan seperti biaya benih, biaya pupuk, biaya obat-obatan, dan biaya tenaga kerja. Rata-rata biaya variabel yang dikeluarkan oleh petani jagung hibrida di Desa Cihaur Kecamatan Maja adalah sebesar Rp2.471.232,03 per satu kali musim tanam atau tiga bulan. Uraian biaya usahatani yang dikeluarkan oleh petani responden dapat dilihat pada Tabel 3. 
Tabel 3. Rata - rata Biaya Produksi pada Usahatani Jagung Hibrida, 2020

\begin{tabular}{lrr}
\hline \multicolumn{1}{c}{ Uraian } & Nilai (Rupiah) & Persentase (\%) \\
\hline Biaya Variabel & & \\
1. Bibit/Benih & $404.351,56$ & 10,97 \\
2. Pupuk & $557.247,66$ & 15,12 \\
3. Obat - obatan & $38.539,06$ & 1,05 \\
4. Tenaga kerja & $1.471 .093,75$ & 39,90 \\
a. Tenaga kerja luar keluarga & $1.425 .312,50$ & \\
b. Tenaga kerja dalam keluarga & $45.781,25$ & 27,25 \\
Biaya Tetap & & 0,29 \\
5. Sewa lahan/perkiraan sewa lahan & $1.004 .687,50$ & 5,43 \\
6. Pajak Lahan & $10.625,00$ & $\mathbf{1 0 0 , 0 0}$ \\
7. Penyusutan & $200.023,44$ & \\
\hline Total Biaya Produksi & $\mathbf{3 . 6 8 6 . 5 6 7 , 9 7}$ & \\
\hline Sumber: Data primer, Diolah (2020) & &
\end{tabular}

Berdasarkan Tabel 3, total biaya produksi pada usahatani jagung hibrida di Desa Cihaur adalah sebesar Rp3.686.567,97 per 0,77 ha per satu kali musim tanam. Biaya paling tinggi yang dikeluarkan pada usahatani jagung hibrida di Desa Cihaur adalah biaya membayar tenaga kerja sebesar 39,9\% yang terdiri dari tenaga kerja dalam keluarga dan luar keluarga sedangkan biaya paling kecil adalah biaya pajak lahan sebesar 0,29\% dari total biaya.

Benih. Benih yang digunakan pada usahatani jagung hibrida pada lokasi penelitian sebagian besar diperoleh di toko saprotan terdekat menggunakan modal dari petani sendiri dengan varietas BISI-18, BISI-226, dan NK-212. Dari ketiga varietas benih tersebut, sebagian besar petani menggunakan BISI-18 sebagai benih untuk usahatani jagung hibrida mereka, dengan harga Rp75.000 per bungkus dengan rata-rata penggunaan benih sebanyak 4-6 kg per hektar. Penggunaan benih jagung hibrida BISI18 dikarenakan benih tersebut memiliki keunggulan yaitu tahan terhadap penyakit karat daun dan hawar daun, selain itu potensi hasil panen dari benih BISI-18 dapat mencapai 12 ton per hektar pipilan kering dimana rata-rata yang dapat dihasilkan oleh benih jenis lain hanya 9,1 ton per hektar pipilan kering (Distanpangan, 2016). Biaya yang dikeluarkan untuk benih adalah $\mathrm{Rp}$ 404.351,56 atau 10,97\% dari total biaya.

Pupuk. Usahatani jagung hibrida menggunakan dua jenis pupuk yang dibagi menjadi pupuk organik dan pupuk an-organik. Jenis pupuk organik yang digunakan oleh sebagian besar petani adalah jenis pupuk kandang yang berasal 
dari kotoran ayam. Penggunaan pupuk organik dari bahan alami seperti jerami, kotoran ternak dan biomas dari jagung dinilai dapat memperbaiki kualitas lahan secara intensif (Syam'un dan Ala, 2010). Harga pupuk kandang dalam kilogram adalah $\mathrm{Rp} 500$ dengan rata-rata penggunaan sebanyak 30 kilogram per hektar. Sedangkan untuk pupuk anorganik, terdiri dari pupuk urea, KCL, SP-36 dan Phonska. Jumlah pupuk anorganik yang digunakan adalah sebanyak 3 kuintal per hektar untuk urea dengan harga Rp 1.800/kg, 1 kuintal untuk SP-36 dengan harga Rp2.000/kg, dan 1 kuintal untuk Phonska dengan harga $\mathrm{Rp}$ $2.300 / \mathrm{Kg}$. Biaya yang dikeluarkan untuk pupuk adalah Rp557.247,66 atau 15,12\% dari total biaya.

Obat-obatan. Penggunaan obatobatan dalam usahatani jagung hibrida tidak terlalu dibutuhkan oleh petani. Sebagian besar petani hanya menggunakan obat untuk rumput liar untuk mencegah terhambatnya tumbuh tanaman dengan gramoxone, yang merupakan salah satu cara pengendalian gulma pada tanaman jagung hibrida secara selektif yaitu herbisida yang dapat mengendalikan gulma tanpa mengganggu tanaman pokoknya (Wijaya, 2016). Ratarata jumlah gramoxone yang digunakan adalah dengan harga Rp65.000/liter. Adapun insektisida yang digunakan adalah fastac dengan harga Rp155.000/liter. Biaya yang dikeluarkan untuk obat-obatan adalah sebesar Rp38.539,06 atau 1,05\% dari total biaya.

Tenaga Kerja. Tenaga kerja memiliki peranan yang sangat penting dalam menjamin keberlanjutan usahatani dan diperlukan dalam seluruh tahapan usahatani mulai dari tahap persiapan lahan, penanaman dan penyulaman, pemeliharaan, panen, hingga pengangkutan. Tenaga kerja yang digunakan dalam usahatani jagung hibrida terdiri dari tenaga kerja dalam dan luar keluarga. Di dalam setiap kelompok tenaga kerja terdapat tenaga kerja laki-laki dan perempuan dengan tenaga kerja yang cenderung digunakan dalam usahatani jagung hibrida ini adalah tenaga kerja laki-laki. HOK yang digunakan dalam penelitian ini adalah HOK yang berlaku di Desa Cihaur dimana satu HOK sama dengan 5 jam kerja dalam satu hari. Berdasarkan hasil penelitian, tenaga kerja yang digunakan oleh responden rata-rata sebesar 87,06 HOK. Penelitian yang dilakukan oleh Purwanto et al (2015) mendapatkan bahwa tenaga kerja yang digunakan dalam usahatani jagung hibrida adalah 
sebesar 56,17 HOK dalam satu musim tanam, HOK tersebut masih tergolong rendah dan memungkinkan adanya penambahan penggunaan HOK. Rata-rata upah tenaga kerja yang dikeluarkan untuk tenaga kerja laki-laki adalah Rp50.000 dan perempuan adalah Rp40.000 per HOK. Petani responden lebih banyak menggunakan tenaga kerja luar keluarga dibanding tenaga kerja dalam keluarga. Persentase tenaga kerja luar keluarga yang digunakan adalah sebesar 38,66\% sedangkan tenaga kerja dalam keluarga sebesar $1,24 \%$ dari total biaya.

Lahan. Lahan yang digunakan oleh petani jagung hibrida di Desa Cihaur adalah lahan milik sendiri dan lahan sewa. Rata-rata luas lahan yang ditanami jagung hibrida adalah 0,77 Ha. Berdasarkan penelitian yang dilakukan oleh Purwanto et al (2015) didapatkan bahwa rata-rata luas lahan responden petani jagung hibrida hibrida adalah 1,18 Ha. Biaya sewa lahan merupakan biaya yang harus dikeluarkan oleh petani yang termasuk kedalam biaya produksi. Ratarata biaya yang dikeluarkan dalam menyewa lahan adalah Rp1.004.687,5 dengan persentase sebesar $27,25 \%$ dari total biaya. Petani juga diharuskan untuk membayar pajak lahan yang dilakukan satu tahun sekali dengan rata-rata biaya sebesar Rp10.625.

Penyusutan Alat. Alat yang digunakan oleh petani responden dalam melakukan usahatani jagung hibrida berasal dari alat yang dibawa sendiri oleh buruh tani, seperti cangkul dan sabit sedangkan alat yang dimiliki sendiri oleh petani hanya sprayer dan mesin pompa air sehingga petani hanya memiliki cangkul dan sabit dengan jumlah yang sedikit. Rata - rata biaya penyusutan alatalat pertanian yang digunakan pada usahatani jagung hibrida di Desa Cihaur adalah sebesar Rp200.023,44 dengan persentase $5,43 \%$ dari total biaya.

\section{Analisis Pendapatan Usahatani Jagung} Hibrida

Petani dalam memenuhi produksinya, harus mengeluarkan biaya yang akan berpengaruh terhadap pendapatan usahatani itu sendiri. Pendapatan usahatani merupakan selisih antara pendapatan kotor usahatani dengan total biaya yang dikeluarkan pada saat melakukan usahatani (Purwanto et al, 2015). Pendapatan usahatani pada penelitian ini adalah sebesar Rp6.070.791,41 per 0,77 ha per satu kali musim tanam yang merupakan selisih dari penerimaan sebesar Rp9.757.359,38 
dengan biaya produksi sebesar Rp3.686.567,97. Harga jual jagung hibrida pada saat penelitian adalah Rp3.385,94 per kilogram dengan jumlah produksi sebesar 2.865 kilogram sehingga didapatkan penerimaan usahatani sebesar Rp9.757.359,38 per satu kali musim tanam. Purwanto et al (2015) dalam penelitiannya terkait dengan Analisis Produksi dan Pendapatan Usahatani Jagung Hibrida di Desa Modo Kecamatan Bukal Kabupaten Buol mendapatkan pendapatan usahatani sebesar Rp5.071.746 per ha per satu kali musim tanam. Jumlah produksi sebesar 4.533 kilogram dan harga jual Rp2.500 per kilogram sehingga menghasilkan penerimaan sebesar Rp11.332.627 per ha per satu kali musim tanam. Hal ini menunjukkan bahwa pendapatan maupun penerimaan usahatani jagung hibrida pada penelitian ini masih tergolong rendah.

Kelayakan usahatani jagung hibrida dilihat dari analisis $\mathrm{R} / \mathrm{C}$ dan $\mathrm{B} / \mathrm{C}$ Ratio. R/C (Revenue Cost Ratio) merupakan pembagian antara penerimaan dengan biaya total. Berdasarkan hasil penelitian, diketahui nilai R/C Ratio sebesar 2,65 yang menunjukkan bahwa setiap penambahan biaya satu rupiah biaya akan menghasilkan pendapatan sebesar 2,65 rupiah. Usahatani jagung hibrida di Desa Cihaur dikatakan menguntungkan untuk diusahakan.

Hal ini sesuai dengan penelitian yang dilakukan oleh Tahir dan Suddin (2017), pada Analisis Pendapatan Usahatani Jagung pada Lahan Sawah dan Tegalan di Kecamatan Ulaweng yang didapatkan bahwa rasio $\mathrm{R} / \mathrm{C}$ usahatani jagung pada lahan sawah dan tegalan bernilai lebih dari satu maka usahatani tersebut dikatakan layak dan menguntungkan. Sedangkan untuk B/C (Benefit Cost Ratio) didapatkan dari pembagian antara pendapatan dengan biaya total. Berdasarkan hasil penelitian, diketahui nilai B/C Ratio sebesar 1,62. Usahatani jagung hibrida di Desa Cihaur dikatakan layak untuk diusahakan dengan nilai $\mathrm{B} / \mathrm{C}$ lebih besar dari satu $(\mathrm{B} / \mathrm{C}>1)$.

\section{KESIMPULAN DAN SARAN}

\section{Kesimpulan}

Berdasarkan hasil dan pembahasan yang telah dilakukan, didapatkan kesimpulan bahwa biaya produksi per 0,77 ha per satu kali musim tanam pada usahatani jagung hibrida di Desa Cihaur Kecamatan Maja Kabupaten Majalengka masih tergolong rendah. Begitupun dengan pendapatan maupun penerimaan yang didapatkan oleh petani jagung 
hibrida per 0,77 ha per satu kali musim tanam di Desa Cihaur Kecamatan Maja Kabupaten Majalengka masih berada di bawah rata - rata pendapatan pada usahatani jagung hibrida lainnya. Berdasarkan analisis $\mathrm{R} / \mathrm{C}$ dan $\mathrm{B} / \mathrm{C}$ ratio, usahatani jagung hibrida dikatakan layak dan menguntungkan untuk diusahakan karena nilai $\mathrm{R} / \mathrm{C}$ dan $\mathrm{B} / \mathrm{C}$ Ratio lebih besar dari $1(\mathrm{R} / \mathrm{C}>1$ dan $\mathrm{B} / \mathrm{C}>1)$.

\section{Saran}

Petani jagung hibrida di Desa Cihaur perlu meningkatkan hasil produksinya dengan harga jual yang sudah ada dengan penggunaan input produksi yang sebaiknya digunakan sesuai dengan rekomendasi dari pemerintah sehingga diharapkan dapat meningkatkan pendapatan maupun penerimaan usahatani dengan biaya produksi yang efisien.

\section{DAFTAR PUSTAKA}

Badan Pusat Statistik. (2019). Provinsi Jawa Barat Dalam Angka tahun 2019.

Badan Pusat Statistik. (2019). Nilai Produksi dan Biaya Produksi per Musim Tanam per Hektar Budidaya Tanaman Padi Sawah, Padi Ladang, Jagung dan Kedelai.

Badan Pusat Statistik. (2019). Provinsi Jawa Barat Dalam Angka tahun 2019.
Badan Pusat Statistik. (2018). Kabupaten Majalengka Dalam Angka tahun 2018.

Badan Pusat Statistik. (2017). Kabupaten Majalengka Dalam Angka tahun 2017.

Badan Pusat Statistik. (2016). Kabupaten Majalengka Dalam Angka tahun 2016.

Badan Pusat Statistik. (2015). Kabupaten Majalengka Dalam Angka tahun 2015.

Dinas Tanaman dan Pangan. (2016). Penggunaan Pupuk SP-36 Meningkatkan Produksi Tanaman Jagung di Desa Candimulyo. Retrieved from Dinas Tanaman dan Pangan Kabupaten Magelang: https://distanpangan.magelangkab.g o.id/home/detail/penggunaanpupuk-sp-36-meningkatkanproduksi-tanaman-jagung-di-desacandimulyo/130\#: : :text=Jagung $\% 2$ 0hibrida $\% 20$ BISI $\% 2$ D 18\%20memp unyai,filling)\%20bisa\%20mencapai $\% 2097 \% 25$.

Mubyarto. (1989). Pengantar Ekonomi Pertanian. Yogyakarta: LP3ES.

Purwanto, A. Z., Hadayani, \& Muis, A. (2015). Analisis Produksi dan Pendapatan Usahatani Jagung Hibrida di Desa Modo Kecamatan Bukal Kabupaten Buol. Jurnal Agroland Vol.22 No.3, 205-215.

Pusat Data dan Sistem Informasi Pertanian. (2018). Outlook

Komoditas Pertanian Tanaman Pangan Jagung. Indonesia: Kementrian Pertanian.

Siregar, N. M. (2011). Analisis Pendapatan Usahatani dan Faktor - Faktor yang Mempengaruhi Produksi Cabai Merah Keriting di Desa Citapen, Kecamatan Ciawi, Kabupaten Bogor. Bogor: Institut Pertanian Bogor.

Shinta, A. (2011). Ilmu Usahatani. Malang: Universitas Brawijaya. 
Syam'un, E., \&Ala, A. (2010). Produksi Tanaman Jagung pada Dua Jenis Pupuk Organik, Paket Pemupukan, dan Dosis Mikoriza Vasikular Arbuskular (MVA). Jurnal Agrivigor Vol 9 No.2, 177-190.

Tahir, A. G., \& Suddin, A. F. (2017). Analisis Pendapatan Usahatani Jagung pada Lahan Sawah dan Tegalan di Kecamatan Ulaweng, Kabupaten Bone Sulawesi Selatan. Jurnal Galung Tropika, Vol. 6 No.1, 1-11.

Wijaya, I. K. (2016). Kajian tentang Gulma pada Budidaya Tanaman Jagung di Desa Munggu, Kecamatan Menguwi, Kabupaten Badung. Bali: Universitas Udayana. 